\title{
ISLAM DAN ILMU PENGETAHUAN DALAM DISKURSUS MUSLIM KONTEMPORER
}

\author{
M. Zainal Abidin*
}

\begin{abstract}
This paper tries to describe the debate on Islam and knowledge in contemporary Moslem thought regarding with two essential issues. Firstly, how to overcome the decline of knowledge in the Moslem society, secondly, how to deal with knowledge produced by Western civilization. Moslem intellectual response differently on the issues, especially in looking at the character of modern knowledge. Some perceive the knowledge as neutral and universal, so if the Moslem wants to take the knowledge, they have to follow the Western knowledge thoroughly. While the others argue that the knowledge is not neutral. It always depends on its maker, so the Moslem must be aware of Western knowledge. Above all, the contemporary of Moslem scholars realize that the only way to the second resurgence to get the golden age of Islam is through mastering the knowledge for the supremacy of knowledge is the main indicator of the supremacy of a civilization.
\end{abstract}

Keywords: Ilmu Pengetahuan, Umat Islam, Peradaban Barat, Pemikiran Muslim Kontemporer.

PERSOALAN Islam dan ilmu pengetahuan merupakan salah satu tema yang paling banyak dibincangkan dalam beberapa dasawarsa terakhir. Diskusi ini berkisar pada dua persoalan krusial, yakni: pertama, bagaimana mengatasi kemerosotan dan ketertinggalan umat Islam dalam bidang ilmu pengetahuan, dan

${ }^{*}$ Dosen Fakultas Ushuluddin IAIN Antasari Banjarmasin, kandidat Doktor (S-3) di Universitas Islam Negeri (UIN) Sunan Kalijaga Yogyakarta. email: zain@scientist.com 
kedua, bagaimana bersikap terhadap ilmu pengetahuan modern yang merupakan produk peradaban Barat.

Perbincangan kedua persoalan di atas pada prakteknya sering terkait dan tidak bisa dipisahkan. Ketika berbicara tentang ketertinggalan umat Islam di bidang ilmu pengetahuan, pada saat yang bersamaan juga bisa dipastikan akan mendiskusikan kemajuan dan pencapaian ilmu pengetahuan oleh peradaban Barat, serta sikap umat Islam terhadapnya, demikian juga sebaliknya.

Respon intelektual muslim kontemporer yang ikut ambil bagian dalam perdebatan tersebut sangatlah beragam. Ia merupakan bagian dari arus besar pemikiran muslim setelah kekalahan bangsa Arab oleh Israel pada tahun 1967, yang kemudian melahirkan kritik diri dan berikutnya menjadi titik tolak untuk menyambut kebangkitan kembali dunia Islam (islamic resurgence), yakni bagaimana bersikap terhadap tradisi (turâts) dan modernitas (hadatsah). ${ }^{1}$ Dan salah satu dari produk modernitas adalah ilmu pengetahuan.

Diskusi tentang Islam dan ilmu pengetahuan ini melibatkan banyak intelektual dari berbagai negara, seperti Malaysia, Pakistan, Inggris, Amerika Utara, Mesir, dan Indonesia. Tidak hanya sebatas pada tataran wacana, perdebatan ini sudah merambah level praksis. Lahirnya berbagai disiplin keilmuan seperti ekonomi Islam, psikologi Islam, sosiologi Islam, penelitian Islam, dan sebagainya merupakan bagian dari produk perdebatan tersebut. Kegelisahan intelektual muslim akan realitas ketertinggalan umat Islam pada berbagai aspek

${ }^{1}$ Ada beberapa idiomatik atau istilah yang biasa dipergunakan para pemikir Arab kontemporer, yaitu: al-turâts wa al-hadâtsah (Mohammed 'Abid al- Jâbirî); al-turâts wa al-tajdîd (Hassan Hanafi); al-ashlah wa al-hadâtsah (A.H. Jidah); al-turâts wa al-mu'âshirah (A.D. Umari); dan dalam bentuk yang tidak konsisten dipergunakan juga al-qadìm wa al-jadîd (Hassan Hanafi). Seluruh istilah yang disebut ini memiliki arti tradisi dan modernitas dengan makna seluas-luasnya. 
kehidupan yang berpangkal dari persoalan ilmu pengetahuan, telah mendorong mereka untuk terlibat secara aktif baik pada tataran teoritis maupun praktis dalam diskusi mengenai Islam dan ilmu pengetahuan.

Pada tulisan ini akan dikemukakan peta respon pemikir muslim terhadap ilmu pengetahuan modern yang merupakan produk peradaban Barat. Secara khusus, akan diulas mengenai perdebatan sekitar islamisasi ilmu yang merupakan isu panas yang sampai sekarang masih terus bergulir, baik yang setuju maupun yang menentangnya serta berbagai varian interpretasi terhadapnya. Untuk lebih memahami persoalan, sebelum itu akan dikemukakan secara singkat kondisi keterpurukan umat setelah mereka pernah menjadi "superior" selama beberapa abad, yang kemudian berpindah ke Barat.

\section{Dinamika Ilmu Pengetahuan di Dunia Muslim}

Umat Islam pernah menorehkan kegemilangan peradaban pada sekitar abad VII sampai dengan abad XIII Masehi, bahkan beberapa abad setelahnya pengaruh itu masih sangat terasa kuat di Eropa. Pada abad-abad yang dikenal sebagai the golden age of Islam ini, kaum muslim menjadi mercusuar peradaban dunia dan pelopor kecemerlangan ilmu pengetahuan. Peradaban muslim menjadi rujukan dari umat-umat lain. Bahasa Arab menjadi bahasa internasional dalam bidang keilmuan, yang harus dikuasai oleh mereka yang hendak mendalami bidang yang satu ini.

Pada masa kejayaannya, dunia Islam dikenal dengan para ilmuwannya yang menguasai beragam displin keilmuan, misalnya di bidang teologi ada al-Asy'âri (W. 935) dan al-Maturî̀î (W. 944), di bidang sastra seperti al-Jâhiz (W. 780) dan Ibn Qutaybah (W. 828), di bidang sejarah dan geografi ada al-Baladhûrî (W. 820) dan al Ya'kûb (W. 897), di bidang sufisme ada al-Muhâsibî (W. 857), Abû Yazîd al-Bustâmî (W. 875), dan al-Hallâj (W. 922), di bidang kedokteran seperti al-Râzîi (W. 923-32) dan Ibn Sînâ ( W. 1037), di bidang matematika dan astronomi seperti al- 
Khwarizmi (W. setelah 846) dan Ibn Haitsam (W. 1039), dan di bidang filsafat ada al-Kindi, al-Farabi (W. 870), Ibn Sina (W. 980), dan lain-lain. Merekalah di antara para ilmuwan yang menandai hingar bingarnya peradaban muslim.

Kemajuan di bidang ilmu pengetahuan yang dicapai oleh umat Islam selama berabad-abad tersebut diperoleh melalui ikhtiar yang kuat dengan motivasi yang didorong oleh agama. Sinergisitas yang bagus antara penguasa (pemerintah) dengan para ilmuwan disertai dengan adanya tradisi ilmiah atau budaya ilmu yang sangat kuat menjadikan pencapaian yang luar biasa dari bangsa terkebelakang (Arab Badui) dan tidak pernah diperhitungkan dalam percaturan peradaban menjadi pemimpin peradaban dan memberikan sumbangan yang sangat berharga pada bidang keilmuan seperti astronomi, matematika, kimia, fisika, hingga filsafat, yang kemudian menjadi tonggak kemajuan dan pencapaian ilmu pengetahuan dunia modern saat ini.

Setelah beberapa abad berada di puncak peradaban dunia, umat Islam memasuki fase kemunduran. Nasib tragis menimpa umat yang pernah memimpin peradaban ini. Mereka mengalami kehinaan dan ketertindasan dalam penjajahan. Kemiskinan dan kebodohan menjadi sesuatu yang melekat padanya. Nurcholish Madjid pernah memberikan ilustrasi tentang realitas yang menyedihkan dari umat ini dengan mengatakan:

Dewasa ini dunia Islam praktis merupakan kawasan bumi yang paling terkebelakang di antara penganut agama-agama besar. Negeri-negeri Islam jauh tertinggal dari Eropa Utara, Amerika Utara, Australia dan Selandia Baru yang Protestan; Eropa Selatan dan Amerika Selatan yang Katolik Romawi; Eropa Timur yang Katolik Ortodoks; Israel yang Yahudi; India yang Hindu; Cina (giant dragon), Korea Selatan, Taiwan, Hongkong, dan Singapura (little dragon) yang BudhistKonfusianis; Jepang yang Budhis Taois; dan Thailand yang Budhist. Praktis tidak satu pun agama besar di muka bumi ini yang lebih rendah kemajuan ilmu pengetahuan dan teknologi 
(iptek)-nya daripada Islam. Dengan perkataan lain, di antara semua penganut agama besar di muka bumi ini, para pemeluk Islam adalah yang paling rendah dan lemah dalam hal sains dan teknologi. ${ }^{2}$

Gambaran tentang perkembangan ilmu pengetahuan (sains) di dunia muslim juga dipotret dengan sangat menarik dalam jurnal sains paling bergengsi Nature, edisi 2 Nopember 2006. Laporan yang dibagi dalam sembilan bagian itu menyajikan data singkat perkembangan sains dunia sejak zaman kekhalifahan Bani Abbasiyah yang berpusat di Baghdad hingga Bani Usmaniyah di Istambul. Saat itu, Eropa masih sangat terbelakang dalam soal sains dan teknologi.

Disajikan pula pandangan kontemporer tentang perkembangan riset ilmu pengetahuan di negara-negara Islam saat ini. Disebutkan dalam laporan itu, perkembangan sains di dunia Islam tak merata kemajuannya. Negara-negara Islam di Afrika Utara masih berkutat dengan masalah kemiskinan dan masalah sosial dan ekonomi sehingga tak menunjukkan kemajuan dalam bidang sains. Sedangkan di negara-negara Teluk yang kaya minyak, rupanya berkah petrodolar tidak serta merta membangkitkan riset sains. Negara teluk yang dianggap maju dalam sains adalah Iran yang terwakili oleh proyek riset nuklir dan persenjataan militer. Sedangkan Turki, satu-satunya anggota OKI yang juga anggota Uni Eropa, memacu dirinya dalam riset sains karena ingin mensejajarkan diri dengan masyarakat Eropa yang lain. Di anak benua Asia, Pakistan juga pelopor dalam riset sains khususnya dalam persenjataan nuklir.

Meski ada beberapa negara muslim yang relatif dianggap maju dalam pengembangan sains dan teknologi, namun secara umum disimpulkan bahwa negara-negara muslim tidak memiliki konsern yang bagus terhadap perkembangan sains. Bahkan

2Lihat Nurcholish Madjid, Kaki Langit Peradaban Islam Jakarta: Paramadina,1997), 21-2. 
anggaran untuk riset dan pengembangan (research and development) sangat rendah apabila dibandingkan dengan rata-rata anggaran global. Selain itu, data-data riset yang dimiliki pada 57 negaranegara muslim yang tergabung dalam organisasi konferensi Islam (OKI) juga tidak jelas dan akurat. Dinyatakan:

"Stretching from Indonesia to Morocco, and from Uganda to Kazakhstan, countries with large Muslim populations are home to some 1.3 billion people. The Islamic world encompasses remarkable diversity in political systems, geography, history, language and culture. But science in these nations is weak, with spending on research and development far lower than the global average. The official statistics database of the Organization of the Islamic Conference (OIC) reveals information on each of the 57 OIC nations on everything from arable land per tractor to Internet users, but you won't find any data on research. Science indicators for OIC countries are also scarce among data collected by the World Bank and United Nations agencies - largely a reflection of many of these countries' low level of interest in science." 3

Kondisi miris di negara-negara muslim ini sangat jauh berbeda, misalnya dengan pencapaian yang diperoleh bangsa Yahudi. Bangsa ini memiliki perhatian yang sangat besar terhadap ilmu pengetahuan. Menurut catatan statistik, rasio jumlah penduduk Yahudi dengan jumlah ilmuwan mereka yang bergelar doktor dalam berbagai disiplin ilmu adalah yang terbesar di dunia, 1 juta berbanding 16.000 dan para ilmuwannya telah memperoleh penghargaan 161 Hadiah Nobel.

\section{Supremasi Barat dan Kesadaran Diri}

Berkebalikan dengan kemunduran di dunia muslim, Barat secara perlahan membangun peradabannya melalui seri perubahan revolusioner seperti revolusi keilmuan, revolusi Perancis, revolusi industri, profesionalisasi ilmu, interaksi rapat antara ilmu dan teknologi, dan revolusi-revolusi abad XX dalam

${ }^{3}$ Lihat www.nature.com. diakses pada 1 Februari 2007. 
ilmu yang berkesimbangunan yang bukan saja mempengaruhi dunia Barat sendiri, tetapi juga seluruh dunia.

Menurut Cemil Akdogan, profesor sejarah sains di ISTACIIUM, penguasaan pada bidang ilmu sains inilah rahasia sejati kemajuan Barat. Ia merupakan kerja abstrak yang kemudian berbuah pada kemampuan teknologi. Secara salah kaprah bangsa-bangsa Islam mengidentifikasi peradaban Barat dengan piranti teknologi seperti kendaraan, alat-alat listrik, televisi, radio, telepon, pesawat, senjata nuklir, dan sebagainya, kemudian mencoba mengimitasinya yang pada akhirnya merugikan diri sendiri. Kemampuan teknologi Barat adalah aplikasi pengetahuan ilmiah. Tanpa penguasaan landasan ilmiah, hanya memproduksi piranti-piranti teknologi melalui imitasi sangatlah berisiko. Bangsa-bangsa muslim menurutnya, tidak akan pernah mengambil alih kepemimpinan ilmiah dari Barat, supremasi Barat dalam teknologi berbasis sains akan terus berlanjut. ${ }^{4}$

Di tengah dominasi peradaban Barat, kesadaran akan ketertinggalan umat menyeruak dalam diri para inteletual muslim. Lemahnya penguasaan pada ilmu pengetahuan adalah kunci dari ketertinggalan ini. Para pemikir seperti Muhammad Abduh, Seyyed Hossein Nasr, Fazlur Rahman, Ismail Razi alFaruqi, Syed Muhammad Naquib al-Attas, dan Ziauddin Sardar adalah di antara mereka yang prihatin dan sangat bersemangat dalam upaya mencari solusi ketertinggalan umat Islam di bidang yang satu ini.

Muhammad Abduh misalnya, yang dianggap sebagai salah satu ikon pembaharu Islam di abad modern, menyatakan bahwa ketertinggalan umat Islam di bidang ilmu pengetahuan adalah akibat adanya sikap statis pada diri mereka. Menurutnya:

"...secara ajaran, Islam sarat dengan semangat yang menggugah ilmu pengetahuan. Ketertinggalan umat Islam, adalah lebih karena sikap

4Lihat Cemil Akdogan, "Asal-usul Sains Modern dan Kontribusi Islam”, Islamia, 4 (Januari-Maret 2005), 93-4. 
mereka yang statis (jumud). Agama selalu berjalan berdampingan dengan akal untuk mengarungi lautan ilmu, menjelajahi permukaan bumi dan naik ke lapisan langit tinggi, untuk menyelidiki tanda-tanda kekuasaan Allah dan rahasia ciptaan-Nya. Manakala paham keagamaan membeku dan penuntut-penuntut ilmu pengetahuan sudah tidak giat lagi, maka itupun turut membeku pula." 5

Selain introspeksi terhadap ketertinggalan ilmu pengetahuan pada dunia muslim, para pemikir muslim kontemporer memiliki pandangan beragam terhadap ilmu pengetahuan modern yang merupakan produk Barat. Pada satu sisi ada kelompok yang memujanya sedemikian rupa, dan mengharuskan umat Islam untuk meniru Barat apabila juga ingin maju, pada sisi lain, tampil sekelompok ilmuwan yang kritis terhadap Barat, dengan menyatakan bahwa ilmu pengetahuan Barat selain memiliki kontribusi dalam memajukan dunia, pada saat yang sama juga memiliki peran yang besar dalam melahirkan berbagai problema dan krisis kemanusiaan manusia modern. Hal ini terjadi dikarenakan pengabaiannya kepada yang sakral (Tuhan) dan penolakannya terhadap wahyu sebagai salah satu sumber ilmu. Di sinilah, peran umat Islam kemudian dituntut untuk mengambil alih kembali posisi penguasa peradaban, sehingga ilmu pengetahuan yang dihasilkan akan benar-benar memberikan maslahat, tidak hanya bagi umat Islam secara khusus, tetapi juga umat manusia secara keseluruhan.

\section{Respons Pemikir Muslim Kontemporer}

Pertanyaan sekarang, bagaimanakah para pemikir muslim memberikan respon terhadap ketertinggalan umat Islam dan dominasi ilmu pengetahuan Barat? Sebagai bagian dari ikhtiar merebut kembali supremasi ilmu pengetahuan, ada banyak varian pemikir muslim yang berbicara tentang hal ini, namun

${ }^{5}$ Lihat Syekh Muhammad Abduh, Ilmu dan Peradaban menurut Islam dan Kristen, ter. Mahyiddin Syaf \& A. Bakar Usman (Bandung: CV Diponegoro, 1978), 121. 
secara umum berdasarkan orientasi pemikirannya, dapat dikelompokkan pada tiga kelompok besar yakni; pertama, kelompok affirmatif-apologetik; kedua, kelompok instrumentalis, dan ketiga, kelompok kritis.

\section{Kelompok Affirmatif-Apologetik.}

Kelompok ini mengasumsikan bahwa ajaran Islam adalah ajaran yang sudah lengkap dan berbicara tentang semua hal, ilmu pengetahuan. Al-Qur'an yang merupakan rujukan utama dalam agama Islam telah meliputi semua bidang keilmuan. Dengan asumsi ini, semua penemuan ilmiah Barat itu pada dasarnya sudah ada dalam al-Qur'an. Dalam bentuk yang lebih konkrit, kelompok ini berusaha mengafirmasi atau menjustifikasi penemuan-penemuan tersebut dengan ayat-ayat al-Qur'an.

Salah satu pemikir yang termasuk kategori ini, yakni Maurice Bucaille. Dengan karyanya Asal Usul Manusia Menurut Bibel, Al Qur'an dan Sains (1988), Bucaille, yang merupakan ahli bedah bangsa Perancis, berusaha menyesuaikan antara al-Qur'an dengan berbagai temuan ilmiah modern dan karyanya ini sangat terkenal dan best seller di negara-negara muslim.

Metode Bucaille pada dasarnya sederhana. Dia meminta para pembacanya untuk merenungkan beberapa ayat al-Qur'an. Dari berbagai pengertian yang dapat diberikan ayat itu, dia menarik satu yang sesuai dengan fakta ilmiah. Dia lalu menyimpulkan bahwa, bila Bibel sering salah dalam menggambarkan gejala alam, maka al-Qur'an selalu benar dan dengan tepat mengantisipasi semua penemuan besar sains modern.

Untuk mencapai ini, dia menyusun sejumlah rujukan alQur'an yang mengesankan mengenai lebah, laba-laba, burung, tumbuh-tumbuhan dan berbagai sayuran, susu binatang, embrio, dan reproduksi manusia. Bahasannya tentang benda mati berkisar dari planet-planet tata surya, galaksi dan materi antar bintang, sampai pada pengembangan alam semesta dan penaklukan ruang angkasa. Dia mengakhiri pembahasan masing- 
masing masalah dengan kesimpulan bahwa kesesuian yang mengagumkan dari wahyu-wahyu al-Qur'an dengan fakta-fakta ilmiah merupakan bukti akan sifat mu'jizat al-Qur'an. ${ }^{6}$

Metode yang digunakan Buccaille ini sangat terkenal, sering disebut sebagai Buccaillisme. Bagi banyak umat Islam, dengan segela keterpurukan dan inferioritas mereka di bidang ilmu pengetahuan, apa yang dilakukan Buccaille ini dapat memuaskan psikologi mereka, dan membuat mereka tenang berhadapan dengan supremasi peradaban Kristen Barat.

Namun, bagi sementara pemikir muslim lain, apa yang dilakukan Buccaille ini bisa berbahaya. Pervez Hoodbhoy, seorang pakar fisika dari Pakistan misalnya menyatakan bahwa bagi orang yang beriman dan berakal, setidaknya ada dua kekurangan yang fundamental dari metodologi Buccaille ini:

Pertama, bukti dari suatu preposisi hanya akan bermakna jika kemungkinan ketidakterbuktian preposisi itu juga ditampakkan. Apa artinya kita asumsikan bahwa jumlah sudut segi tiga sama dengan 180 derajat, dan kemudian kita buktikan hal itu. Orangorang beriman mengetahui bahwa dalam segala hal al-Qur'an mustahil salah, maka sejak awal semua usaha untuk pembuktian sifat kewahyuannya sudah sepenuhnya benar dari awal.

Kedua, adalah sangat berbahaya untuk menggantungkan suatu kebenaran abadi pada teori sains yang dapat berubah. Pemahaman kita mengenai alam semesta dapat berubah secara drastis sejalan dengan waktu. Dan sains tidak sungkan-sungkan meninggalkan teori lamanya dan mendukung yang baru. Tidakkah akan menjadi bencana jika sesorang berusaha untuk menambatkan suatu gagasan teologis pada pasir yang hanyut ini. ${ }^{7}$

Karena itu, menyetarakan wahyu yang bersifat sakral dan memiliki kebenaran absolut dengan penemuan ilmiah yang sifat

${ }^{6}$ Lihat Maurice Bucaille, Asal Usul Manusia Menurut Bibel, Al Qur'an dan Sains, ter. Rahmani Astuti (Bandung: Mizan, 1998), 52.

${ }^{7}$ Lihat Pervez Hoodbhoy, Islam and Science: Religious Orthodoxy and the Battle for Rationality (London: Zed Books, 1991), 123-4. 
kebenarannya relatif akan bermasalah ketika temuan ilmiah yang dijustifikasi tersebut kemudian dianggap tidak relevan lagi dan direvisi dengan temuan-temuan yang baru. Akibatnya, kebenaran wahyu sebagai "alat pembenar" juga akan dapat turut serta merta menjadi tereduksi.

\section{Kelompok Instrumentalis}

Kelompok ini berpandangan bahwa ilmu pengetahuan atau sains itu sekadar alat dan tidak terikat pada nilai atau agama tertentu. Ilmu pengetahuan menurut mereka bersifat netral dan universal. Ia dapat diumpamakan sebagai sebuah pisau. Baik buruknya tergantung kepada sang pemakai. Bagi ibu-ibu, pisau dapat dipergunakan untuk memotong sayur atau mengupas buah, namun bagi seorang preman pisau merupakan senjata ampuh untuk melukai orang lain.

Dengan asumsi seperti ini, maka jalan satu-satunya untuk mengejar ketertinggalan umat Islam, yakni dengan melakukan transfer ilmu pengetahuan dan teknologi dari dunia Barat ke dunia Islam. Sayid Jamaluddin al-Afghani (1838-1897) adalah salah satu tokoh, yang meski dikenal sangat anti imperialisme, tetapi sangat mengagumi pencapaian ilmu pengetahuan Barat. Ia tidak melihat kontradiksi antara Islam dan ilmu pengetahuan. Menurutnya, Barat mampu menjajah kawasan Islam karena memiliki ilmu pengetahuan dan teknologi, oleh sebab itu kaum muslim harus juga menguasainya agar dapat melawan imperalisme Barat. ${ }^{8}$ Gagasan al-Afghani ini cukup populer di dunia Islam. Penerus utama gagasan al-Afghani yang terkenal adalah Muhammad Abduh (1849-1905) dan Muhammad Rasyid Ridha (1865-1935). Keduanya sempat mengunjungi beberapa negara Eropa dan sangat terkesan dengan pengalaman mereka di

8Lihat Zainal Abidin Bagir, "Pergolakan Pemikiran di Bidang Ilmu Pengetahuan", dalam Ensiklopedi Tematis Dunia Islam, ed. Taufik Abdullah et al (Jakarta: Ichtiar Baru van Hoeve, 2002), 138. 
sana. Bagi Abduh dan Ridha, ilmu pengetahuan modern adalah baik, yang menjadi masalah adalah tujuan penggunaannya.

Pemikir lain yang berpandangan instrumentalis ini dapat kita temukan pada sosok Fazlur Rahman. Menurutnya bahwa ilmu itu pada dasarnya adalah baik, yang membuatnya buruk adalah penyalahgunaannya. Namun keputusan untuk menyalahgunakannya tidak tergantung pada ilmu itu sendiri, tetapi pada prioritas moral. Umat Islam, menurut Rahman, seharusnya tidak perlu bersusah payah untuk membuat rencana dan bagan bagaimana menciptakan ilmu pengetahuan yang islami. ${ }^{9}$

Pandangan instrumentalis yang mengasumsikan ilmu pengetahuan yang netral ini kemudian mendapatkan kritikan yang keras di tengah maraknya anggapan bahwa peradaban dan ilmu pengetahuan Barat yang sarat dengan nilai dan kepentingan Barat, bersifat destruktif terhadap kemanusiaan dan tidak dapat memenuhi kebutuhan materil, kultural, dan spiritual umat manusia.

\section{Kelompok Kritis}

Berlawanan dengan semangat kaum instrumentalis yang melihat netralitas ilmu pengetahuan. Kelompok ini menilai ilmu pengetahuan tidak ada yang netral, tetapi selalu bias nilai dari penyusunnya. Kelompok ini merupakan kelompok yang berpandangan kritis terhadap ilmu pengetahuan modern produk Barat. Sejatinya kekritisan mereka itu juga banyak didukung oleh pendapat ilmuwan Barat sendiri terhadap perkembangan sains yang berlaku di Barat. Adapun pemikir muslim yang terlibat dalam hal ini, umumnya adalah pemikir yang berdomisili di Barat

'Lihat Fazlur Rahman, "Islamization of Knowledge: A Response", dalam American Journal of Islamic Social Sciences 5: 1 (1988), hal. 3-11; dalam edisi Indonesia "Islamisasi Ilmu Sebuah Respon", dalam Jurnal Ulumul Qur'an, 4 (1992), 68-72. 
atau setidaknya merupakan lulusan dari salah satu universitas terkenal di Barat.

Seyyed Hossein Nasr misalnya, mengungkapkan keprihatinannya terhadap sifat sekuler sains modern yang dianggapnya tidak mengakui kenyataan ilahiah dan posisinya sebagai sumber ilmu. Sains modern menurutnya telah melakukan penindasan epistemologi dengan cara tidak mengakui cara-cara pandang lain terhadap alam, termasuk yang ada dalam agama. Kepercayaan akan realitas di luar realitas empirik hanya dianggap sebagai mitos atau takhayul belaka. ${ }^{10}$

Kehilangan terhadap aspek yang sakral, demikian dinyatakan oleh C.A. Qadir telah mengakibatkan pengasingan dan pemisahan dalam kehidupan manusia modern. Terdapat ketidakseimbangan dan ketertiban. Jiwa manusia mengalami penyakit schizophrenia kerohanian, yang tidak mempunyai jalan keluar kecuali dengan kembali kepada Sumber Primordial dan menghidupkan kembali aspek kesakralan ini. ${ }^{11}$ Sementara itu Ziauddin Sardar menolak solusi dampak negatif ilmu pengetahuan Barat dengan penambahan etika Islam. Menurutnya, argumen ini tidak sah karena dampak ilmu pengetahuan modern juga menyangkut soal kognitif sehingga perumusan epistemologi juga diperlukan. ${ }^{12}$

Kritikan terhadap konsep ilmu Barat juga diungkapkan oleh Naquib al-Attas yang menurutnya lebih banyak menimbulkan masalah dan kekeliruan daripada melahirkan keharmonisan, kebaikan, dan keadilan. Ilmu Barat ujarnya telah kehilangan tujuan hakiki karena tidak dicerna dengan adil. Akibatnya ia membawa kekacauan dalam kehidupan manusia dan bukannya

\footnotetext{
10Seyyed Hossein Nasr, Knowledge and the Sacred (New York: Crossroad, 1989), 33.

${ }^{11}$ C.A. Qadir, Philosophy and Science in the Islamic World (London: Routledge, 1988), 5.

12Ziauddin Sardar, Exploration in Islamic Science (London: Mansell, 1989), 70 .
} 
kedamaian dan keadilan. Ilmu yang nampaknya benar tetapi lebih produktif ke arah kekeliruan dan skeptisme, ilmu yang buat pertama kali dalam sejarah, membawa kekacaubalauan pada isi alam semesta; hewan, tumbuhan, dan logam. ${ }^{13}$

Secara lebih sistematis, kelompok yang kritis ini kemudian menyampaikan suatu gagasan yang bernama islamisasi ilmu pengetahuan, dan dinyatakan sebagai pilihan terbaik bagi upaya untuk membangun kembali superioritas umat Islam di bidang ilmu pengetahuan tanpa harus tercabut dari nilai-nilai keislamannya. Gerakan ini marak menjelang akhir dasawarsa 1970-an dan tetap eksis sampai sekarang.

Ide islamisasi ilmu secara konseptual bermula dari al-Attas. Dia telah memaparkan ide-idenya pada satu persidangan pendidikan yang sangat penting dalam sejarah umat Islam kontemporer, yaitu Persidangan Pertama Pendidikan Islam sedunia di Mekah pada tahun 1977, yang dihadiri tidak kurang dari 313 sarjana dan pemikir Islam dari seluruh pelosok dunia. Di forum itu ia menyampaikan kertas kerja yang berjudul Preliminary Thoughts on the Nature of Knowledge and the Definition and Aims of Education, yang menjelaskan tentang sifat ilmu yang tidak netral dan islamisasi ilmu-ilmu. Ide ini selanjutnya disempurnakannya lagi dengan terbitnya buku The Concept of Education in Islam: $A$ Framework for an Islamic Philosophy of Education, di samping buku yang telah terbit sebelumnya yang berjudul Islam and Secularism.

Berikutnya, gagasan islamisasi ilmu ini mengalami perkembangan yang cukup signifikan, dan melahirkan varianvarian penafsiran. Namun, secara umum asumsi yang dikembangkan oleh para penggagas ide ini bahwa ilmu pengetahuan modern yang merupakan produk ilmuwan Barat, tidak bebas nilai dan sarat dengan pandangan dunia (worldview) ${ }^{14}$

${ }^{13}$ Syekh M. Naquib al-Attas, Islam and Secularism (Kuala Lumpur: ABIM, 1978), 217.

${ }^{14}$ Secara kebahasaan worldview atau pandangan hidup sering diartikan filsafat hidup atau prinsip hidup. Ada beberapa istilah yang sering digunakan 
dari para perumusnya. Karenanya umat Islam tidak dapat serta merta mentransfer ilmu pengetahuan dan teknologi yang dihasilkan Barat, tetapi harus dilakukan penyaringan terlebih dahulu, dan memberikan nilai-nilai Islam terhadapnya.

\section{Sekitar Islamisasi Ilmu Pengetahuan}

Sebagaimana dijelaskan di atas, wacana islamisasi ilmu pengetahuan pertama kali diperkenalkan oleh Naquib al-Attas, dan kemudian mendapat sambutan hangat di mana-mana. Berikutnya, berbagai macam tafsiran dan pemaknaan pun muncul terhadap gagasan itu. Salah seorang cendikiawan muslim berpengaruh yang mempopulerkan gagasan islamisasi ilmu ialah Ismail al-Faruqi seorang cendikiawan yang juga aktivis gerakan Islam yang terkenal di Amerika Utara. Melalui International Institute of Islamic Thought (IIIT), digalakkanlah program islamisasi ilmu dalam disiplin-disiplin ilmu mutakhir di samping mengolah ilmu-ilmu baru dalam kerangka tauhid dan syariah.

Secara umum, ada perbedaan mendasar antara proyek islamisasi ilmu yang digagas oleh al-Attas dengan yang dipopulerkan oleh al-Faruqi dan IIT serta aktivis gerakan Islam lainnya, yang akan kita sebut sebagai islamisasi ilmu populer. Berikut akan dikemukakan beberapa perbedaan tersebut:

Pertama, secara definitif, al-Attas menyatakan bahwa islamisasi merupakan pembebasan manusia, pertamanya dari tradisi tahyul, mitos, animis, kebangsaan, dan kebudayaan, kemudian pembebasan akal dan bahasanya dari pengaruh sekularisme. ${ }^{15}$ Di sini al-Attas lebih memperhatikan pada

untuk memaknai pandangan hidup worldview (Inggris); weltanschauung atau weltansicht (Jerman), terkadangan juga paradigm. Dalam pemikiran Islam dikenal juga beberapa istilah dengan makna serupa seperti al tasawnur alislâmi (Sayyid Qutb); al Mabda' al Islâmî (Shaykh Atif al Zayn), Islâmî Nazariyat (al Maududi) dan ru'yat al Islam li al-wujûd (Syed Muhammad Naquib Al Attas).

${ }^{15} \mathrm{Al}$-Attas, Islam..., 41. 
persoalan individu manusianya melalui pemahaman yang jelas terhadap fitrah insaniah. Sedangkan al-Faruqi memaknai islamisasi ilmu sebagai kerangka normatif dan meyeluruh bagi individu dan masyarakat untuk pemikiran dan tindakan, pendidikan dan amalan, pengetahuan dan organisasi, pemerintah dan yang diperintah, dan dunia kini dan dunia yang akan datang. ${ }^{16} \mathrm{Di}$ sini persoalan politik dan masyarakat lebih diunggulkan.

Kedua, secara operasional islamisasi ilmu al-Attas dimulai dari adanya penanaman akan pandangan alam Islam (islamic worldview) dalam kehidupan individu seorang muslim, ${ }^{17}$ baru kemudian proses islamisasi ilmu pun berlaku secara serentak. Ilmu menurut al-Attas berada dalam akal manusia dan bukan di luar diri mereka. Karenanya, islamisasi akal dan pandangan alam amatlah penting untuk dilaksanakan terlebih dahulu sebelum islamisasi ilmu itu boleh dilaksanakan.

Dalam islamisasi ilmu populer. persoalan pandangan alam tidaklah begitu penting. Islamisasi ilmu bagi mereka lebih merupakan islamisasi disiplin-disiplin berbagai ilmu. Dan yang ditekankan ialah persoalan islamisasi metodologi disiplin-disiplin ilmu tersebut. Maka lahirlah misalnya teori-teori islamisasi antropologi, islamisasi ekonomi, islamisasi sains komputer, islamisasi geologi, dan bermacam-macam lagi islamisasi disiplin.

Islamisasi ilmu populer tidak begitu peduli akan sistem nilai pandangan dunia (worldview) Barat sekuler serta kerangka falsafah, metafisika, dan epistemologi yang membentuk tradisi

${ }^{16}$ Ismail Raji al-Faruqi, Islamization of Knowledge: General Principle and Workplan (Washington: IIT, 1982), 84.

${ }^{17} \mathrm{Al}$ Attas menyebut ada sembilan komponen pembentuk pandangan dunia islam, yakni: (1). Hakikat Tuhan; (2) Wahyu/Al Qur'an; (3) Penciptaan; (4) Hakikat Kejiwaan Manusia; (5) Ilmu; (6) Agama; (7) Kebebasan; (8) Nilai dan Kebajikan; (9) Kebahagiaan. Lihat Hamid Fahmy Zarkasyi, "Worldview Sebagai Asas Epistemologi Islam," Islamia, 5 (AprilJuni, 2005), 13. 
keilmuan dan disiplin-disiplin ilmu modern. Penyokong islamisasi ilmu populer, yang umumnya terdiri dari aktivis gerakan Islam, sangat menentang bidang filsafat dan metafisika. Mereka juga menolak hampir keseluruhan tradisi keilmuan Islam terutama yang berkaitan dengan tradisi filsafat, kalam, dan tasawuf. Akibat dari sikap anti-tradisi ilmu Islam ini, pendukung islamisasi ilmu populer terpaksa mencari model untuk tujuan islamisasi disiplin dari luar kerangka tradisi ilmu Islam itu sendiri, yakni Barat. Karenanya, kritikanpun banyak dialamatkan kepada gerakan islamisasi populer ini.

Sementara itu, gagasan awal yang dirintis al-Attas menghendaki islamisasi ilmu mestilah dibina di atas satu kerangka falsafah, metafisika dan epistemologi yang benar menurut pandangan Islam. Kerangka dasar ilmu dipahami dengan jelas oleh para cendikiawan muslim sebelum diterapkan dalam konteks disiplin-disiplin ilmu masing-masing. Oleh karena itu, setiap cendikiawan muslim terlebih dahulu harus memahami agama mereka sendiri, memiliki pandangan alam Islam yang tepat, menguasai kerangka metafisika Islam dan seterusnya baru melaksanakan program islamisasi ilmu.

\section{Catatan Akhir}

Secara umum harus diakui bahwa dalam perdebatan sekitar Islam dan ilmu pengetahuan ini, keterlibatan intelektual Indonesia umumnya sangat minim, meski juga bukan berarti tidak ada yang merespons terhadap gagasan ini. Bahkan, respons yang dilakukan pada beberapa tahun terakhir sudah tidak semata dalam bentuk wacana, tetapi sudah pada tingkat implementasi. Maraknya ekonomi Islam, perbankan syariah, psikologi Islam, kiranya tidak lepas dari produk gagasan islamisasi ilmu.

Demikian juga perubahan dari IAIN Jogjakarta dan Jakarta serta STAIN Malang menjadi UIN, yang berupaya untuk melakukan integrasi antara Islam dan ilmu pengetahuan serta meniadakan dikotomi ilmu pengetahuan yang telah menjadikan 
umat Islam tersisihkan dari percaturan ilmu pengetahuan, tampaknya juga lahir dari kesadaran akan adanya hubungan yang sangat erat antara Islam dengan ilmu pengetahuan.

Pada satu sisi kita patut bersyukur bahwa ghirah untuk kembali kepada Islam marak di kalangan umat dan kesadaran untuk merebut kembali kendali peradaban dan mengisinya dengan nilai-nilai Islam (kemanusiaan) juga tertanam kuat, namun semua itu hanya akan menjadi kontraproduktif apabila tidak dilandasi pemahaman akan paradigma keilmuan Islam yang jelas, yakni paradigma yang berangkat dari filsafat, epistemologi, dan metafisika yang berlaku dalam Islam.

Sebagai catatan akhir dari paparan yang telah dikemukakan di atas, dapat disimpulkan beberapa hal sebagai berikut:

Pertama, ada kesadaran yang massif akan ketertinggalan umat Islam dan pentingnya penguasaan ilmu pengetahuan sebagai upaya untuk meraih kembali kejayaan Islam. Ini kiranya menjadi modal dasar yang sangat bagus bagi umat dalam upaya membangun kembali supremasi ilmu pengetahuan yang menjad indikator kemajuan sebuah peradaban.

Kedua, ada perbedaan cara pandang intelektual muslim terhadap ilmu pengetahuan. Sebagian melihat bahwa ilmu itu netral sehingga bisa berlaku secara universal, sebagian yang lain, dan ini yang kiranya lebih bisa diterima, bahwa ilmu itu tidak netral, ia sarat dengan bias nilai para perumusnya, karenanya sikap kritis terhadap ilmu pengetahuan Barat harus terus dilakukan.

Ketiga, berkenaan dengan gagasan islamisasi ilmu, ada dua pandangan besar. Pertama, oleh al-Attas yang berpandangan bahwa islamisasi berangkat dari islamisasi individu berupa islamisasi akal dan pandangan dunia, sementara islamisasi kedua, yang populer yakni oleh al-Faruqi menyatakan bahwa islamisasi itu adalah islamisasi disiplin-disiplin ilmu. Dalam hal ini, kiranya model al-Attas lebih logis dan realistis.

Wa al-Lâh a lam bi al-shawâb. 


\section{Daftar Pustaka}

C. A. Qadir, Philosophy and Science in the Islamic World (London: Routledge, 1988).

Cemil Akdogan, "Asal-usul Sains Modern dan Kontribusi Islam", Islamia, 4 (Januari-Maret, 2005).

Fazlur Rahman, "Islamization of Knowledge: A Response", American Journal of Islamic Social Sciences, 5 (1988); dalam edisi Indonesia "Islamisasi Ilmu Sebuah Respon”, Ulumul Qur'an, 4 (1992).

Hamid Fahmy Zarkasyi, "Worldview Sebagai Asas Epistemologi Islam,” Islamia, 5 (April-Juni 2005).

Ismail Raji al-Faruqi, Islamization of Knowledge: General Principle and Workplan (Washington: IIT, 1982).

Maurice Bucaille, Asal Usul Manusia Menurut Bibel, Al Qur'an dan Sains, ter. Rahmani Astuti (Bandung: Mizan, 1998).

Nurcholish Madjid, Kaki Langit Peradaban Islam (Jakarta: Paramadina, 1997)

Pervez Hoodbhoy, Islam and Science: Religious Orthodoxy and the Battle for Rationality (London: Zed Books, 1991).

Seyyed Hossein Nasr, Knowledge and the Sacred (New York: Crossroad, 1989).

Syed M. Naquib al-Attas, 1978, Islam and Secularism (Kuala Lumpur: ABIM, 1978).

Syekh Muhammad Abduh, Ilmu dan Peradaban menurut Islam dan Kristen, ter. Mahyiddin Syaf \& A. Bakar Usman (Bandung: CV Diponegoro, 1978).

www.nature.com. diakses pada 1 Februari 2007. 
Zainal Abidin Bagir, "Pergolakan Pemikiran di Bidang Ilmu Pengetahuan", dalam Ensiklopedi Tematis Dunia Islam, ed. Taufik Abdullah et al (Jakarta: Ichtiar Baru van Hoeve, 2002). Ziauddin Sardar, Exploration in Islamic Science (London: Mansell, 1989). 